\title{
BASIC PRINCIPLES OF THE MECHANISM OF ENSURING SOCIAL AND ECONOMIC SECURITY
}

\author{
CShvaiba D., ORCID: 0000-0001-6783-9765, Ph.D., \\ Belarusian Trade Union of workers of chemical, mining and oil industries, \\ Belarusian national technical University, Minsk, Belarus, shvabia@tut.by

\section{ОСНОВНЫЕ ПРИНЦИПЫ МЕХАНИЗМА ОБЕСПЕЧЕНИЯ СОЦИАЛЬНО-ЭКОНОМИЧЕСКОЙ БЕЗОПАСНОСТИ}

\author{
СШвайба Д. Н., ORCID: 0000-0001-6783-9765, канд. экон. наук, \\ Белорусский профсоюз работников химической, горной и нефтяной отраслей \\ промышленности, Белорусский начиональный технический университет, \\ 2. Минск, Беларусь, shvabia@tut.by
}

Abstract. The choice of the hierarchical principle of the structural organization of the mechanism of ensuring socio-economic security is consistent with the presentation of the role of its components in the regulation of financial and economic processes. Thus, in the performance of the functions of defense, the role of the components of the mechanism in the schemes of direct and current relations, information channels, management conclusions and administrative work is inevitable. Apart from this, the inter-element relations of the mechanism of ensuring social and economic security are mediated by financial and economic relations and, first of all, commoditymoney, which are based on the coordination and specific subordination of financial and economic interests. This means that the process of ensuring social and economic security must not be strictly subordinate to the hierarchy of public administration, and be one of its intensive components, which plays a dual role. On the one hand, it has the ability to be needed as the 1st of the methods of implementation of the state financial and economic interests. But, on the other hand, the method is intended to act as a "signal link" to adjust the provisions of the financial and economic policy in an environment of large-scale dangers, which to some extent refutes its subordination to the previously adopted management conclusions. For example, the study of the structuring of the mechanism of ensuring social and economic security implemented in the Republic of Belarus shows its obvious subordinate nature in the system of public administration. In particular, the element distribution of the presented mechanism was made in coordination with the hierarchy of the management system of economic entities. This means that its capabilities are used only to some extent due to the level of restrictions in the implementation of socio-economic security. Level limitation of the control system leads to the fact that financial and economic regulators of the state and functioning of mesostructures have all chances to be "included" in absolute measure at the macro level and only partly — at the micro level.

Аннотация. Выбор иерархического принципа структурной организации механизма обеспечивания социально-экономической безопасности согласуется с представлением роли его составляющих в регулировке финансово-экономических процессов. Так, при выполнении функций обороны неизбежна роль составляющих механизма в схемах прямых и оборотных связей, информационных каналах, управленческих заключениях и административной работы. Не считая этого, межэлементные связи механизма обеспечивания социально-экономической безопасности опосредованы финансово-экономическими отношениями и, в первую очередь, 
товарно-денежными, которые основаны на согласовании и конкретной подчиненности финансово-экономических интересов. Это значит, что процесс обеспечивания социальноэкономической безопасности обязан представлять не строго подчиненный характер по сравнению с иерархией госуправления, а быть одним из интенсивных его составляющих, который играет двойственную роль. С одной стороны, он имеет возможность быть необходимым в качестве 1-го из методов реализации государственных финансовоэкономических интересов. Но, с иной стороны, способ призван выступать «сигнальным звеном» для корректировки положений проводимой финансово-экономической политики в обстановке проявления масштабных опасностей, что в определенной степени опровергает его подчиненность принятым ранее управленческим заключениям. К примеру, исследование структурирования реализуемого в Республике Беларусь механизма обеспечивания социально-экономической безопасности показывает на его явный подчиненный характер в системе госуправления. В частности, элементное распределение представленного механизма было совершено в согласовании с иерархией системы управления работой хозяйствующих субъектов. Это значит, что его возможности применяются только в некоторой степени в силу уровневых ограничений в реализации задач социально-экономической безопасности. Уровневые лимитирования системы управления приводят к тому, что финансовоэкономические регуляторы характеристик состояния и функционирования мезоструктур имеют все шансы быть «включены» в абсолютной мере на макроуровне и только отчасти на микроуровне.

Keywords: socio-economic security, government, society, enterprise, employee, threat, security, interests, economics, analysis, system.

Ключевые слова: социально-экономическая защищенность, государство, общество, предприятие, работник, угроза, защищенность, интересы, экономика, анализ, система.

Dynamic stability of the economy largely depends on the capabilities of the mechanism to ensure socio-economic security, which justified its compatibility with the system of public administration [1, p. 192]. For purposeful formation of this possibility, a conceptual model of the organizational mechanism is proposed, which allows to coordinate the provisions of the policy with the tasks of defense of state financial and economic interests. According to the model, the subject structure performing functions on ensuring social and economic security orients, keep under control and correct a situation in relation to the purpose - achievement and maintenance of value of nondangerous functioning of economy of the state. Based on the purpose of the mechanism and the role in the defense system, its functionality makes sense to implement the principle of controllability. In particular, to give the quality of controllability it makes sense to distribute the interelement connections by the levels of subordination (hierarchical principle) [2]. This will provide an opportunity to implement the functions of ensuring socio-economic security harmoniously, according to the priority of their importance and in coordination with the status of the entity implementing the function.

The choice of the hierarchical principle of the structural organization of the mechanism of ensuring socio-economic security is consistent with the representation of the role of its components in the regulation of financial and economic processes. Thus, when performing the functions of defense, the role of the components of the mechanism in the schemes of direct and reverse relations, information channels, management opinions and administrative work is inevitable. Apart from this, the inter-element relations of the mechanism of ensuring socio-economic security are mediated by 
financial and economic relations and, first of all, commodity-money, which are based on the coordination and specific subordination of financial and economic interests $[3 ; 4 ; 5]$. This means that the process of ensuring social and economic security must not be strictly subordinate to the hierarchy of public administration, but be one of its intensive components, which plays a dual role. On the one hand, it has the ability to be needed as the 1st of the methods of realization of state financial and economic interests. But, on the other hand, the method is intended to act as a "signal link" to adjust the provisions of the financial and economic policy in the context of the manifestation of large-scale dangers, which to some extent refutes its subordination to previously adopted management conclusions. For example, the study of the structuring of the mechanism of ensuring social and economic security implemented in the Republic of Belarus shows its obvious subordinate nature in the system of public administration. In particular, the element distribution of the presented mechanism was made in coordination with the hierarchy of the management system of economic entities. This means that its capabilities are used only to some extent due to the level restrictions in the implementation of socio-economic security. Level limitations of the control system lead to the fact that financial and economic regulators of the characteristics of the state and functioning of mesostructures have all chances to be "included" in absolute measure at the macro level and only partly-at the micro level. This explains the current practice, in which preference is given to measures of administrative response to the shift to the worst state of the financial and economic sphere. Its results lead to the fact that the reaction of the economy to these measures has the ability to be more quickly, but the result is most often considered the preservation of the negative state at a particular stage. The root cause is the limitations of the" administrative resource " and the conditional narrowness of the previously formed legal framework and generally recognized business rules. Thus, the proven precedent is the objective inertia of the legislative framework, which is aimed at regulating the processes in relation to the current conditions, but it may not be sufficiently adapted to the upcoming conditions. As a result, this design of the mechanism is able to effectively perform the functions of defense of state financial and economic interests only in relation to those threats that have repeatedly appeared, been overcome and the specifics of their impact investigated. But to influence of the fresh dangers generated as a rule by an external environment, its design is a little prepared, in connection with the fact that the dispersion of components is put depending on the hierarchy of management. At the same time, operational, constantly updated information about the change in the value of socio-economic security is not always necessary for the authorities and, therefore, the adjustment of its characteristics is performed with a delay. The above says that the conceptual basis of the existing mechanism of ensuring social and economic security is developed only on the generalized principles of the organization of systems. Subject specificity is not provided in them. At the same time, the need to specify the basis of the formation of the mechanism under consideration is determined by the peculiarities of the role in the defense of the state economy and the methodological base of the structure of the corresponding system. To solve this problem, we studied the Belarusian and foreign experience in the formation of adaptation models, which demonstrated the need to differentiate the basics of the symptom of the purpose into 2 types: formation and functioning (Figure). Shown in Figure bases are distributed on communication and adaptation directions.

This allows you to prevent or reduce to a minimum number of Agency losses due to the mismatch of interests and the emergence of intersubject incidents. The following principles are integrated into the communication framework.

The principle of the primacy of state financial and economic interests without prejudice to the related interests of external entities. The need to comply with this principle in the functioning of the mechanism of socio-economic security is dictated by the processes of internationalization of 
reproduction, globalization and regionalization of the economy, and, in addition, the multi-level structure of security systems (international, regional, collective, national). The openness of the state economy expands the presence in its system of foreign entities, foreign funds and related financial and economic interests. The study shows that by attracting foreign investments in the economy of the state, it is necessary to coordinate its provisions on the characteristics of independence and management. In the formation of a suitable financial climate in the country, a bilateral approach is needed to achieve a balance of interests $[6 ; 7]$.

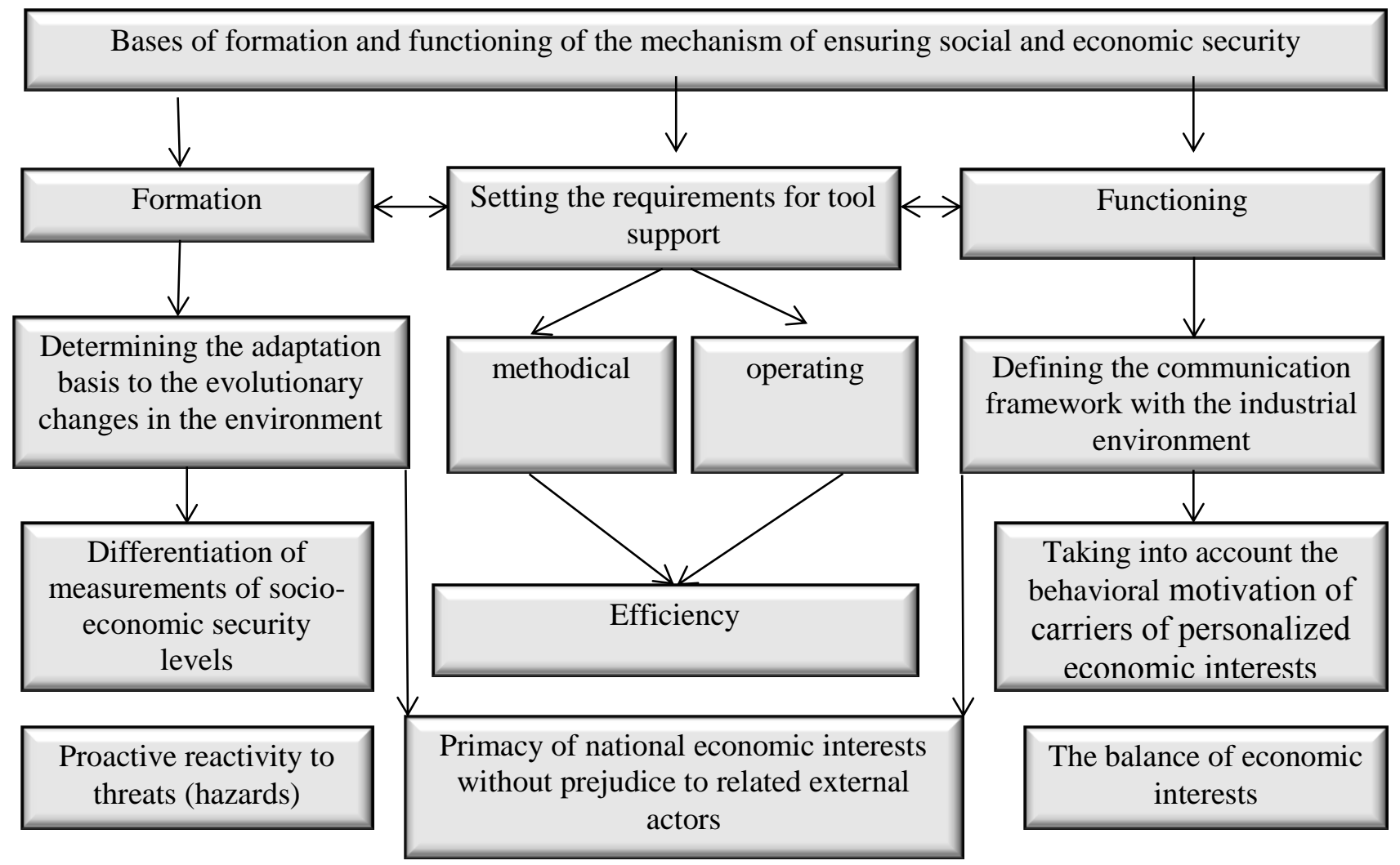

Figure. The scheme of formation of the organizational mechanism of social and economic security

The principle of balancing financial and economic interests. The determining factor of the presented principle is that it takes into account the achievement of a balance of interests, goals and values as an important circumstance of stable development. Drawing up the rules of conduct of the subject, adequate to the conditions of market relations, is a priority in the functioning of structures that ensure socio-economic security, long-term financial and economic growth and identify incentives for the development of the economy of the state. In the context of the principle under consideration, the establishment by society of such generally recognized measures and rules of conduct that would facilitate the preference of the subjects to choose non-confrontational methods of resolving contradictions in the process of realization of their financial and economic interests is considered to be a necessary factor.

For example, foreign scientists propose to apply a system of restrictions based on social and administrative regulators in order to realize the balance of interests. As such, the following are likely to be adopted: informal communication bases cultivated to a specific degree are aimed at non-conflict coexistence and balance of interests of the subjects. 
The principle of differentiation of measurements of the value of socio-economic security is justified by the complexity of the object area of the defense system of financial and economic interests and the expansion of reproductive relations beyond the state borders. The dynamic element discovered by the analysis in the level properties of socio-economic security has led to the need to implement the adjustment of actions to implement the financial and economic interests of the system basis. As a result, the proposed principle of forming a mechanism for ensuring socioeconomic security reflects the change in the criteria for the functioning of economic systems and implies that similar configurations are expected in the future.

\section{References:}

1. Stroeva, O. A., \& Lavrikova, N. I. (2015). Osobennosti realizatsii gosudarstvennoi politiki v sotsial'no-ekonomicheskoi sfere. Srednerusskii vestnik obshchestvennykh nauk, (2). 190-195.

2. Klimuk, V. V. Imperativy ekonomicheskoi bezopasnosti gosudarstva $\mathrm{v}$ novykh ekonomicheskikh usloviyakh. Ekonomicheskie tendentsii. Rezhim dostupa: http://ej.barsu.by/download/1//1_4.pdf. (data dostupa 03.01.2018).

3. Ezerskaya, S. G. Sushchnost' i metody otsenki ekonomicheskoi bezopasnosti // Mezhregional'nyi marketingovyi tsentr "Ivanovo". Rezhim dostupa: http://ivanovo.marketcenter.ru/content/doc-2-435.html. (data dostupa: 17.03.2016).

4. Utkin, E. A., \& Denisov, A. F. (2002). Ekonomicheskaya bezopasnost' regiona // Gosudarstvennoe i regional'noe upravlenie. Moscow, Rezhim dostupa: http://qoo.by/2r0A. (data dostupa: 11.08.2017).

5. Suzdaleva, D. A. Analiz ekonomicheskoi bezopasnosti regiona s primeneniem sistemnodinamicheskogo modelirovaniya. Novaya ekonomicheskaya assotsiatsiya. Rezhim dostupa: http://www.econorus.org/c2013/program.phtml?vid=report\&eid=598. (data dostupa: 11.08.2017).

6. Shvaiba, D. (2018). Structural stability and socio-economic security of the hierarchical system. Bulletin of Science and Practice, 4(6), 233-239.

7. Shvaiba, D. (2018). Socio-economic security of the hierarchical system. Bulletin of Science and Practice, 4(6), 248-254.

\section{Список литературы:}

1. Строева О. А., Лаврикова Н. И. Особенности реализации государственной политики в социально-экономической сфере // Среднерусский вестник общественных наук. 2015. № 2. С. $190-195$.

2. Климук В. В. Императивы экономической безопасности государства в новых экономических условиях // Экономические тенденции. Режим доступа: http://ej.barsu.by/download/1//1_4.pdf. (дата доступа 03.01.2018).

3. Езерская С. Г. Сущность и методы оценки экономической безопасности // Межрегиональный маркетинговый центр «Иваново». Режим доступа: http://ivanovo.marketcenter.ru/content/doc-2-435.html. (дата доступа: 17.03.2016).

4. Уткин Э. А., Денисов А. Ф. Экономическая безопасность региона // Государственное и региональное управление. М., 2002. Режим доступа: http://qoo.by/2r0A. (дата доступа: 11.08.2017).

5. Суздалева Д. А. Анализ экономической безопасности региона с применением системно-динамического моделирования // Новая экономическая ассоциация. Режим доступа: http://www.econorus.org/c2013/program.phtml?vid=report\&eid=598. (дата доступа: 11.08.2017). 
6. Shvaiba D. Structural stability and socio-economic security of the hierarchical system // Бюллетень науки и практики. 2018. Т. 4. №6. С. 233-239.

7. Shvaiba D. Socio-economic security of the hierarchical system // Бюллетень науки и практики. 2018. Т. 4. №6. С. 248-254.

Работа поступила

в редакцию 17.01.2019 г.
Принята к публикации

21.01.2019 2.

Cite as (APA):

Shvaiba, D. (2019). Basic principles of the mechanism of ensuring social and economic security // Bulletin of Science and Practice, 5(2), 222-227. https://doi.org/10.33619/24142948/39/29 (in Russian).

Ссылка для изитирования:

Shvaiba D. Basic principles of the mechanism of ensuring social and economic security // Бюллетень науки и практики. 2019. Т. 5. №2. С. 222-227. https://doi.org/10.33619/2414$2948 / 39 / 29$. 